\title{
Probing the Reflection of Arab Literature on the Sonnets of Sa'adi Shirazi
}

Masumeh Pouya

Farhad Divsalar*

\begin{abstract}
Department of Arabic literature, Faculty of Literature and Foreign Languages, Islamic Azad University, Karaj Branch, Karaj, Iran
\end{abstract}
Corresponding AuthorEmail:divsalarf@yahoo.com; f.divsalar@kiau.ac.ir

\section{Abstract}

The literature of each country is rooted in thoughts and ideas of its intellectuals and poets. Throughout history in Iran, we can see the appearance and development of outstanding poets who have examined their senses and talents in many different styles and have been successful. The intellectual and religious movements have always been influential in appearance of different literary styles or literary themes and their strengths or weaknesses. The appearance of new Arabic combination of words and phrases in romantic and lyric Persian poetry has been influential in creation of new concepts and has led to new style in Persian literature. With appearance of the greatest Persian poet and prose writer, Sa'adi Shirazi in seventh century, the Iraqi style which is characterized with applications of the words are less original Persian and Arabic words instead of them are replaced, reached the peaks and climax of sonnet style. This analytical-descriptive present paper examines the reflection and interactions of Persian and Arabic literature in sonnet of Sa'adi of Shiraz with Iraqi style.

Keywords: Sa'adi Shirazi, Arabic literature, Iraqi style, Sonnet

\section{Introduction}

The development of Literature and literary styles in every historical period is the result of social, economical, historical and cultural situation of each era. Iran as a civilized country with many prominent authors and thinker has always been a productive ground. After the entrance of Islam to Iran, the Persian civilization grew based on two valuable factors, one was the belief in celestial religion of Islam and the other was thousand years of glorious history of Iran. The Islam so influenced in Iranians heart and they accepted it so that it was more than a borrowed religion and finally, Iranians linked it to their past religion and culture. So, by this way, Persian and Arabic literature combined together extensively and generated Islamic Persian Literature. This combination and interaction led to noticeable changes in Persian literature.

In this era, Iraqi style was developed in Persian literature which characterized with applications of the words are less original Persian and Arabic words instead of them are replaced and the great Persian poet Sa'adi reached the peaks and climax of lyric poetry in Iraqi style.

In Sa'adi's works, we can see the Arabic idioms and words derived from Islam, Verses of Quran and Hadith which rooted in essence of Sa'adi from childhood; as well as the spirit of love and mystic of Sa'adi, who was manifested in his works.

Not only Iranians but also critics all over the world have studied and interpreted Sa'adi's ideas, works and literary style. Some critics like Hossein Ali Mahfooz believes that Sa'adi is totally influenced by Motannabi -the great Arab poetwhereas, some Iranian critics believe that Sa'adi is an epitome of Persian poet with entirely Persian thoughts and some critics introduces Sa'adi as the middle of these two extremes.

In the present study, we have tried to introduce the various literary styles in Iran in brief and specially focused on Iraqi style. Then, we analyze the influences reflection and interactions of Persian and Arabic literature in Arabic lyric poetry of Sa'adi Shirazi in Iraqi style.

\section{Material and Methods}

In the present study, we have tried to read all works of Sa'adi Shirazi and only recorded his Arabic poems (especially Arabic lyric poetry) and then, analyzed them in order to preparing relation between these poems with Iraqi style of great Sa'adi. So, present research is a descriptive and library based study in which the eminent chosen elements are traced in the above mentioned work to show the influences of interaction of Arabic and Persian literature in the works of Sa'adi, as a great Persian poet. 


\section{Literary Styles in Iran}

According Cambridge dictionary definition Style (sabk in Persian) means the mode of expressing thought in writing or speaking by selecting and arranging words, considered with respect to clearness, effectiveness, euphony, or the like, that is characteristic of a group, period, person, personality, etc.

In fact Style is the manner of expression; how a speaker or writer says what he says. The style in writing can be defined as the way a writer writes and it is the technique which an individual author uses in his writing. Also, according Dr Moein Dictionary definition, style means the putting melted metal in mold (Moeen, 2002:827). Literary style is a unique way of presenting a piece of writing. The combination of word choice, figurative language, sentence formation, and formality work together to create a 'voice' through which a story is told is considered as a specific literary style. The author's words and the characteristic way that writer uses language to achieve certain effects. An important part of interpreting and understanding fiction is being attentive to the way the author uses words.

Persian poetry has been classified under four popular sabk or styles, namely:

a) Khurasani (Turkistani/ Azarbaijani),

b) Iraqi,

c) Indian (Isfahani) and

d) literary revival return to the old styles of Khurasani and Iraqi.

Appellations of first three groups are according to the name of geographic position of style creation (Divsalar \& Mazhari, 2013).

\subsection{Khorasani style}

Some critics have sub-divided the Khurasani style as Azarbaijani and cited to the pattern of Qatran, Khaqani and Nizami but generally the first style of the Persian Poetry which begins with the advent specimen, of this poetry available from the beginning of the third century A.H. towards the end of sixth century A.H. is generally termed Khurasani as it was the Khurasan area where Persian Poetry flourished during the Samani period and then it reached other parts of ancient Iran. This style is called as Turkistani, too (Bahar, M., 1964).

The followers of this style mostly were associated with Greater Khorasan and has been popular for its Qasidas characterized by its high flown language, supercilious diction, dignified tone, and relatively literate language. This has been a very forceful and vigorous style. The chief representatives of this lyricism are Asjadi, Farrukhi Sistani, Unsuri, and Manuchehri. Panegyric masters such as Rudaki were known for their love of nature, their verse abounding with evocative descriptions. Through these courts and system of patronage emerged the epic style of poetry, with Ferdowsi's Shahnama at the apex. By glorifying the Iranian historical past in heroic and elevated verses, he and other notables such as Daqiqi and Asadi Tusi presented the "Ajam" with a source of pride and inspiration that has helped preserve a sense of identity for the Iranian peoples over the ages. Ferdowsi set a model to be followed by a host of other poets later on (Safa, 1983).

\subsection{Iraqi style}

After the Mongols Mongol invasion to Iran, all of the cultural centers were moved to Persian Iraq (Iraq e Ajam). The Iraqi style, as the second Persian poem style, from the thirteenth to the fifteenth century, is marked by the prominence of lyric poetry (the ghazales), the consequent development of the ghazal into the most significant verse form, and the diffusion of mystical thought. Its style is generally dubbed Iraqi because of the association of some of its earlier exponents with central and western Persia (even though its two major representatives, Saadi and Hafez, were from the southern province of Fars); it is known by its lyric quality, tenderness of feeling, mellifluous meters, and the relative simplicity of its language. The Iraqi style is the most beautiful style of the Persian Poetry. The meanings may be deep and mystic but the words in Iraqi style are found to be of very lucid and fascinating nature. Poets such as Sana'i and Attar, Khaqani Shirvani, Anvari, and Nezami, were highly respected ghazal writers. However, the great Masters of Iraqi style like Rumi, Saadi, and Hafez have used the Arabic words in such an artistic way that they appear to be mild and well-suited (Safa, 1983). The dominant theme in this era is ghazal. The attention to the expressions and exquisites reaches its peak and poets gain various arts.

The crisi in the 7th century poetry was in a way that Saadi reached the peaks and climax of ghazal (Tamimi \& Bohluli, 2015).

From the literary historical books views, some reasons which mentioned for the alteration of Persian poet style in this era are as follow: 
1- Persian language developed and moved from east of Iran toward central and western states of Iran, so it expanded.

2- Persian language mixed and combined more and more with Arabic language and then the new words and idioms were created and produced which can help to poets in order to the expression of their feelings so easier.

3- Poets and writers started to apply examples and documents in Persian poems from holy Quran and prophet Hadithes with high frequency. So, the poets involved mystic and scientific phrases and words into their works and as a result poems and proses of that time lost their simplicity and changed to more figurative language (Safa, 2000: 326).

Three important characteristics of Iraqi style which was famous between the early seventh century to the early tenth century for 300 years are Linguistically, Intellectually and Literally.

\subsection{Hindi style}

This style starts from the fifteenth into the eighteenth century, is also introduced as Isfahani or Safavi style. It has its beginning in the Timurid period and is marked by an even greater prominence of lyric poetry, although it is somewhat devoid of the linguistic elegance and musicality of the preceding period.

Some critics believe that appearance of Safavid dynasty in Iran and Baberieh in India and some social, religious and political changes in tis time has critical roles for beginning and development of Hindi style in Persian poems.

\subsection{Literary Revival Style}

The last period from eighteenth to the mid-twentieth century has known as a Literary Revival (bazgasht-e adabi) style. It features a reaction against the poetic stagnation and linguistic foibles of the late Safavid style, and a return to the Iraqi style of lyric poetry and the Khorasani style.

\section{Sa'adi; The Summit of Iraqi Style}

Persian poet, prose writer and thinker, Muslihuddin Abu Muhammad Abdullah ibn Mushrifuddin Sa'adi Shirazi, also referred to as Shaykh Sa'adi and Sa'adi Shirazi, was born in Shiraz in or around 1200 or 1201. At this time, Shiraz was as a populous and one of the most important cultural centers of Iran. He completed his primary education in Shiraz. Sa'adi was grown in a religious family and his religious education was obvious in his works later. It is notable that on that time, Exception of Greece knowledge, all of the sciences were taught in Arabic language. The end of his elementary education coincides roughly with the invasion of Central Asia by Chingiz Khan and the devastation of Khujand, Samarqand, and Bukhara, the Iranian peoples' most cherished cultural centers. Then, Sa'adi left increasingly turbulent Shiraz for Baghdad where he could study the Arabic language, Arab literature, Islamic Sciences, Law, History, and Islamic theology hadith, the Qur'an, and commentaries on the holy book at the famous Nizamiyyah Academy and attended in Jamaledin AbolFaraj AbdollRahman Mohtaseb class (Moayed Shirazi, 1996: 5). He called him Sheikh. Once his education was complete, the unsettled conditions following the Mongol invasion of Khwarezm and Iran led him to left Baghdad and until 1256, traveled extensively in the Middle East, especially in Syria, Arabia, Egypt, Morocco, and Abyssinia and in the eastern Islamic lands, particularly in Turkistan. In the east, he might have traveled as far as India (Safa, 2001: 596). He is recognized not only for the quality of his writing, but also for the depth of his social thoughts and he widely recognized as one of the greatest masters of the classical literary tradition. In the other hand, Sa'adi, was one of the major Persian poets of the medieval period. He is not only famous in Persian-speaking countries or Muslim countries, but has also been quoted in western sources.

Sa'adi's works reflects upon the lives of ordinary Iranians suffering displacement, plight, agony and conflict, during the turbulent times of Mongol invasion. By returning to Shiraz as an experienced scholar, he started to write his two literary masterpieces, famous all around the world. His best known works are Bostan (The Orchard) completed in 1257 and Gulistan (The Rose Garden) in 1258. Bostan is entirely in verse (epic metre) and consists of stories aptly illustrating the standard virtues recommended to Muslims (justice, liberality, modesty, contentment) as well as of reflections on the behavior of dervishes and their ecstatic practices (Pand Nameh) (Safa, 2011: 669).

Sa'adi is also remembered as a panegyrist and lyricist, the author of a number of odes portraying human experience, and also of particular odes in Persian and Arabic such as the lament on the fall of Baghdad after the Mongol invasion in 1258. His lyrics are found in Ghazaliyat (Lyrics) and his odes in Qasa'id (Odes). He is also known for a 
number of works in Arabic and he collected works includes 65 odes out of which 20 are in Arabic. The peculiar blend of human kindness and cynicism, humor and resignation displayed in Sa'adi's works, together with a tendency to avoid the painful dilemmas, make him the most typical and lovable writer in classic Iranian literature.

He has a number of other works including lyrics and Ghazaliyat which are all collected in a one book called 'Kolliate- Sa'adi'. Some critics believe that Sa'adi was titled "Sheikh" because of his knowledge and found followers who pursued his values and words.

\section{Arabic Poetry and Its Influences on Sa'adi Shirazi's works}

The seventh century in Iran was concurrent with the development of Sufism in Arab countries which was a response to social and cultural situation of this time. Because of Mongol invasion to Iran, Sa'adi's pend thirty years abroad through various Arab countries and cities such as Iraq, Syria, Jerusalem, Basra, Mecca and Medina, .... Then, education, visiting and living in Arab countries, and his curiosity and admiration toward science and his masters and supervisors was so influential in his characteristics and life which lasted through his life. So, we can find tis inflections on all of his works, poems and proses. His works such as Arabic odes or Quassidas (long one rhymed poems) less than 700 couplets involve praise, advices and elegy on death of Almotasam Bellah are as a result of above interactions and efficacy (Moayed Shirazi, 1997: 36). Also, there are a lot of Arabic sentences which used as quotation title and adaptation in his Persian poems. It is notable that the existence of Arabic words and sentences with high frequency in almost poems of Sheikh do not produce any unpleasant but also it can add and double the beauty and sweetness of Sa'adi's words. Some critics and writers believe that all of the Arabic poems and Sa'adi's Mollama'at is approximately 682 verses which only 594 verses are Arabic verses and 88 verses are Mollama verses.

(Moayed Shirazi, 1997:31). It should be mentioned that the influences of Arabic poet especially Motanabi on Sa'adi's works can be investigated from various views as follow:

Sa'adi produced some poems more expressive and eloquent than Motanabbi and also changed the materialistic meaning of the poems to spiritual and etc (Anvar, 2001: 30). Finally, it can be concluded that as a result of well understanding of Arabic literature and language and also introducing with holly Quran and Hadiths, Sa'adi is the master of words.

People in Iran and India believe that Sa'adi's Arabic odes are significant and beautiful but some Arab poets represent that Sa'adi's Arabic odes as average as or even less than average level (Brown, 1954: 678). Whereas, it is notable that Sa'adi as a Persian language poet knew Arabic literature more than any other Persian poet which is related to his stay in Arab countries (Moayed Shirazi, 1997: 64).

Some critics such as Dr Qasem Toyserkani evaluated Sa'adi poems as same as second level Arab poets. Dr. Mohammad Khazaeli said so with caution that "Maybe Arabic odes of Sa'adi are average." On the other hand, Jamil Sedghi al- Zahavi, the famous Iraqi poet, believes that Sa'adi's odes are indicative of accuracy and practice of Sa'adi because he was a unique poet greatest author at that time and also for all of the time (Moayed Shirazi, 1997: 71).

Also, Professor Ehsan Abbas in the introduction of a book by Moayed Shirazi said that "if Sa'adi had only one odes on the fall of Baghdad after the Mongol invasion, this odes is enough to represent his strength and great value in literature" (Moayed Shirazi, 1997: 11).

Despite all of the researches, it is notable that the influences and interactions of Sa'adi from Arab literature and Arabic language and Islam haven't been carefully studied in detail and then, all the opinions and criticisms can't be justified (Moayed Shirazi, 1997:3). The investigation on the inflections of Arab literature on Sa'adi's poems need a vast area of research but what we try to investigate in this research is the study of Arab literary themes on Sa'adi's Arabic poems.

\section{Arabic Themes in Arabic poems of Sa'adi}

Dr Ehsan Abbas believes that Sa'adi's poems investigate only three themes and subjects of:

1) panegyric (eulogy),

2) asceticism

3) sonnet (Ghazal).

The first one is referred to clear pathway toward creativity, the second one is deeply connected to religion and the third one, which is the most favorite of the poet, is an open field of his artistic show and performance especially when it's adorned with mysticism (Moayed Shirazi, 1993:11).

At a glance to Arabic poems of great Sa'adi, we can find various themes of Arabic poetry which are generated from 
social, political and cultural situations and connections with other nations. This study investigates some of the main and noticeable themes in some poems of Sa'adi as an example or model.

\subsection{Description}

Sa'adi's visualizations like Abu Tammam - the great Arab poet- are so tangible and real:

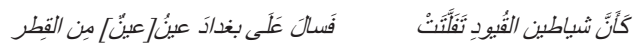

(Sa'adi, 2001:926)

"As if chained devils were released and a fountain of melted copper flowed down Baghdad." (Moayed Shirazi, 1993:81)

Sa'adi's descriptions in Arabic poems are rooted in Arabic environment. With using some Arabic descriptions like describing camel, desert and tribe, Sa'adi gives Arabic color to his poems and also it display his dominance on Divan AlArab.

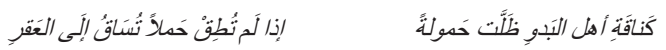

(Sa'adi, 2001:926)

"Your situation is like a camel of desert which carry loads continuously and if camel get unable to carry they take him to altar to be sacrificed." (Moayed Shirazi, 1993:81).

\subsection{Eulogy}

As it is shown in previous historical documents, the Dari Persian poetry has started with praise of kings (Shahidi, 1977:79). After Mongol invasion, Eulogy or the poetry of court didn't totally disappear but it got weak and remained in weakness for a period (Safa, 2011:318).

Eulogy was important in Arabic literature for two reasons, one was for living and business and the other one was the nobility and glory of the person being praised. Sa'adi's eulogy was classified as the second category. He praised most of Atabaks from Salghor, ministers and governors of Fars and some other noblemen of his time (ibid: 602).

But Sa'adi's method in eulogy was novel and he put his own advices and wise thoughts as a base of the eulogy. $\mathrm{He}$, who was grown among "religion scholars" in his family, praised the God before anyone. As he said:

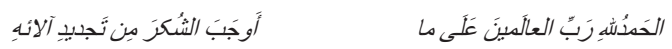

(Sa'adi, 2001:922)

"Praise God whose continuous blessing makes gratitude indispensable."(Moayed Shirazi, 1993:23)

Then, he praises the people (creation of God) whom he knows as blessing of Him:

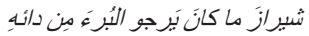

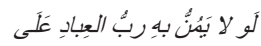

(Sa'adi, 2001:930)

"If the God of people didn't grant him to Shiraz, the pain of this city would not ameliorate" (Moayed Shirazi, 1993:23).

He started and finished this beautiful eulogy with praise of God. So, Sa'adi's eulogy is wise.

\subsection{Elegy}

One of the most important elegies of Sa'adi is on Baghdad in Andolusian style. "This ode is full of human emotions and religious ardor" (Moayed shirazi, 1993:18). The style of this ode is as same as Arab poet's works. As it starts with lyric on beauty of women and the main theme or style is the lyric poems (sonnet), then like Andolusian style, sings for Baghdad:

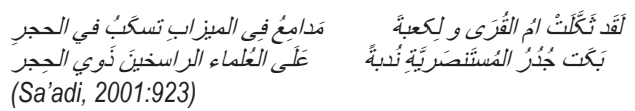


"Mecca is mournful and Kaaba cries its tears into downpipe on Hajjar and the walls of Mostanzaryye bewailed on wise and noble scholars."(Moayed Shirazi, 1993:67).

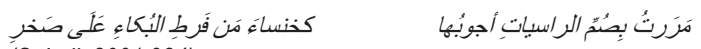

(Sa'adi, 2001:924)

"I passed by silent and firm cliffs, mourning, as if Khansaa is passing by his dead brother Sakhr" (Moayed Shirazi, 1993:69).

\subsection{Preaching and Wisdom}

Sa'adi talks about morality and ethics in all of the works and teaches everybody. It seems that he believes it's his responsibility to lead the society and teach morality to people (Shajiee, 1997:211). Then, he is the wisdom and advisor poet and these points are obvious in all parts of his Persian and Arabic poems.

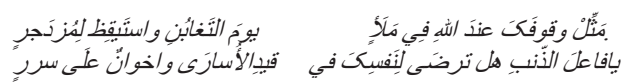

(Sa'adi, 2001:944)

"See yourself with a group of people in doomsday and presence of God. And be vigilant of the advice. Thou wrongdoer! Do you like yourself in chains of slaves and your brothers on thrones?" (Moayed Shirazi, 1993:41).

Or at the beginning of a beautiful poem, he said:

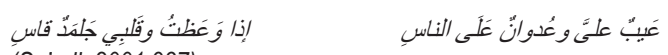

(Sa'adi, 2001:937)

"Being hard in heart and thoughts and in the meanwhile advising people is a dishonor for me and enmity toward people."(Moayed Shirazi, 1993:113).

\subsection{Honor}

Sa'adi is a pearl in ocean of Iraqi style and he knows it himself and he is proud of himself:

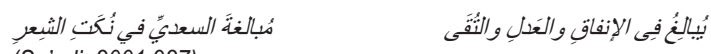

(Sa'adi, 2001:927)

"He like Sa'adi who is brilliant in poems, is excellent in generosity and righteousness." (Moayed Shirazi, 1993:75).

\subsection{Poems on wines (Khamria't)}

Beginning poetry with description of wine in Arab poems had been started in Abbasi period and Abu Novas was the first leading in this style that influenced Sa'adi. In this style instead of weeping over separation or misfortunes, the poet invites the reader to enjoy life and with drinking forget the sadness and just live in present, as Sa'adi said at the beginning of an ode:

$$
\text { قوما اسقيانِي علَى الريحانِ و الآسِ }
$$

(Sa'adi, 2001:940)

"Arise and pour me wine on grass and flowers, I'm heart-broken because of the time passed." (Moayed Shirazi, 1993:109)

Then Sa'adi simulated from Arab poets for expressing of cupbearer. Some believe that this verse is related to masculine Ghazal.

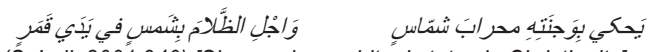

(Śa'adi, 2001:940) [Shamas is a spiritual status in Christianity] 
"Wipe the darkness with the sun you put in hands of a moon, a moon that his face shines like altar of Shamas" (Moayed Shirazi, 1993:109).

This poem of Sa'adi reminds us the Abu Novas's wine poem that he said:

$$
\text { ولا تسقني سرًَا إذا امكنَ الجَهُ }
$$

(Abu Novas, 1970:79)

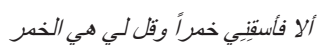

But Sa'adi's wine poems as same as Ibn e Farez are mystical because he is graduated from Nizamyyeh academy and was the student of great mystics such as Sohrevardi and Ghazali. With the spread of mysticism and inclusion of that in Persian poetry, wine and everything which was connected to it changed its literal meaning into figurative, ironic and metaphoric interpretation Sa'adi's wine poems are in this style and they are similar in style to wine poems of Arab literature especially Ibne Farez-e- Mesri (576-632 Hegira):

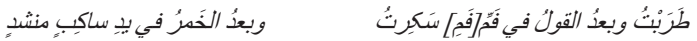

$$
\begin{aligned}
& \text { (Sa'adi, 2001:936) }
\end{aligned}
$$

"The singer hadn't finished his song that I reached mirth and the cupbearer hadn't poured the wine completely that I was intoxicated."(Moayed Shirazi, 1993:25)

\subsection{Themes in Arabic Love Sonnets of Sa'adi}

In classifications of poetic forms, sonnet or lyric poems is a poetry form like odes, quatrains and narrative poetries. But ancient poets have known sonnet as a poetic style and categorized it with panegyric and satire (Dargahi, 1999:154). Sonnet had been important roles in pre-Islamic Arab literature period and it might be said that it was the base of Arabic literature (Sadjjadi, 1982:28). Description of women and lovemaking was the main theme of Arab sonnets but sometimes the theme was divine and heavenly too.

Arab sonneteers are categorized into two groups, the first group live in cities and their sonnets are pornographic and insolent, the other group is nomad sonneteers that have modest sonnets. With spread of mysticism, love poems changed into mystical poems but Sa'adi is skillful in both style of sonnet. The growth of mysticism in sixth century in Iran had great influences on Persian sonnet. Roozbahan Baghli Shirazi was a great mystic who represented his spiritual love in his sonnets. In sonnets of Sa'adi and Hafez, two great Persian poets, the traces of spiritual love of Roozbahan are completely clear (Corbin, 2005:171).

The poetic impact of love on Persian poet is undeniable. Especially Persian poetry is in love's debt. Hafez and Sa'adi's sonnets and Shams's divan are all rooted in love (Dargahi, 1999:96). Sa'adi is the master of Persian sonnet and reached the peak of Persian sonnet (Eqbal Ashtiani, 2005: 541). Sa'adi, whose sonnets are full of love expressions and phrases, has been influenced by this spiritual love. This influence of love, either terrestrial or celestial in Hafez, Sa'adi and Rumi's works, is the best proof that love is both creator and reviving force of poetry (Dargahi, 1998:96).

Roozbahan in Mashreb Al-Arvah described three steps of love, first one is human love, second is spiritual and the third one is the divine love. Human love is a stairway for spiritual love and spiritual love is the stairway of divine love (Baghli, 1973:134).

Dr Eslami Nadooshan described Sa'adi's sonnets as follow: his sonnets are just passion and ecstasy. He explained his spiritual credo with great romantic and mystical ecstasy. In his sonnets, love is hidden and covered in earthly love. Sa'adi believed that earthly love is essential in order to pass the first steps of spirituality. His sonnets introduce youthful excitement and exhilaration of love but there are good examples of spiritual love too. Other great Persian sonneteer, Hafez, has also followed his form of sonnets and odes and even adopted some of his phrases and content (Ashtiani, 2005:541).

On the other hand, Sa'adi's sonnets are Ozri (modest and describe the pure love of lover for the beloved) and they reminds the Arab poets like Jamil Ibn-e- Ma'amar, Gheis Ibn-Al-Malooh (Majnoon) and Obeyd-o-Allah Ibn-e- Gheis -alRaghiyyat whose sonnets have sincere emotions and some aspects of pre-Islamic Arab life can be seen in them. Sa'adi's love poems in Arabic, like his poems in Persian are full of life and dynamism. As he is proud of being in love in Persian poems, he is also proud of it in Arabic sonnets. In Sa'adi's point of view, hiding love is possible only to some extent, as if in the past lovers hid their love as far as they could but when the ardor triumphed them they couldn't stop the flame and their secret was unrevealed. Sa'adi described this feeling so: 
وإن غَلَبَ الشَّوقُ الثَّدبيُُ فباحوا

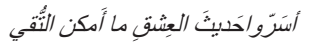

(Sa'adi, 2001:930)

"Lovers tried to abstain from love as far as they could, but when the ardor defeated them, the hidden secret was disclosed" (Moayed Shirazi, 1993:41)

Sa'adi is madly in love and has lost his patience:

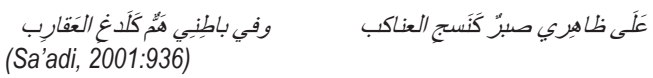

"My appearance shows patience as feeble as spider web, and my inside tolerate a melancholy as strong as scorpion's sting." (Moayed Shirazi, 1993:25)

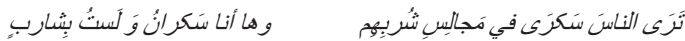

(Sa'adi, 2001:936)

"You find others drunk from drinking, but I am the one without wine." (Moayed Shirazi, 1993:27)

Some of Sa'adi's sonnets have a sad love story like the one starts with "وَإِن سَجَع القُمري" and it describes an earthly love which starts like this:

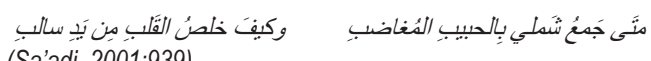

(Sa'adi, 2001:939)

"When will my problems with that fierce beloved finish? How can lover's heart be free of the beloved?" (Moayed Shirazi, 1993:29).

In most of the Arabic love sonnets of Sa'adi the beloved names are either "Leyli" or "Selma" which gives a proper tone of Arabic atmosphere and this point shows how accurate is his familiarity with Arabic sonnets:

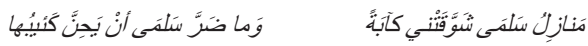

$$
\begin{aligned}
& \text { (Sa'adi, 2001:935) }
\end{aligned}
$$

"The home of Selma made me impatient of grief and there is no harm to her if her lover cries out of longing." (Moayed Shirazi, 1993:35)

" نظم السلوك " is another love sonnet which is homologous with famous ode of Ibn-al-Farez named "متى طلَعَ البدر" in rhyme, meter and even in themes:

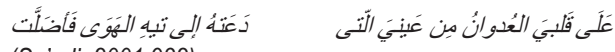

(Sa'adi, 2001:932)

"My eyes were cruel to my heart, those eyes which invited the heart to land of love and made him astray." (Moayed Shirazi, 1993:37)

"مِن كأس المَدامِع "is another love sonnet of Sa'adi in which Arabic atmosphere is so tangible in it. This sonnet is said in sad tone and wail of grief can be heard of it. Sometimes Sa'adi gets so near to precision and nakedness of pornographic Arab poets who described the beautiful body of the beloved:

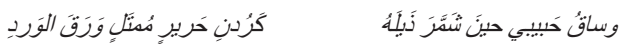

(Sa'adi, 2001:934)

"When she uncovers her legs out of skirt, it's like a silk sleeve adorned with rose petals" (Moayed Shirazi, 1993: 51)

In short, Sa'adi's love sonnets wander between celestial and terrestrial love and pornographic and modest descriptions. Whenever he likes he speaks about the beloved in the most beautiful manner. Unfortunately, we didn't have enough time and space to work on all of his love sonnets but his love is permanent in his Persian and Arabic sonnets and definitely he is the master of love sonnets. 


\section{Conclusion}

Social, political and cultural situation in addition to influences of Islam on people and introversion and contemplation led to development of a literary style in a wide area of Persian (Iraq e Ajam) called Iraqi style. Also, Arabic language which was the language of science and literature at this time could be influential in Iraqi style and then, poets applied this language to express their religious and spiritual ideas. Sa'adi who is the summit of Iraqi style, wrote his Arabic poems under influences of Arabic literary themes and its atmosphere. Sonnet in Sa'adi's poems isn't only a form but also it's a theme to express his vast love. Arabic literary themes are His poem concludes with a number of lines preaching social moral of high value in worldly life, a popular features which distinguishes the poem and places it conspicuously beyond the rivalry of any poem.

It is interesting that Sa'sdi uses a language very grave, sublime, impressive, and diction flowing, soft, gentle and embellished with figures of rhetoric in all of the his works specially in sonnets.

Finally, it can be concluded that Persian poet and prose writer, Sa'adi, widely recognized as one of the greatest masters of the classical lyric literary tradition

\section{Acknowledgments}

The financial support of Research Council of Islamic Azad University, Karaj Branch is highly appreciated.

\section{References}

Baghli Shirazi, R. (1981). Anhar Al-Asheghin, Edited by Henri Karbon,

Brown, E. (1954). Historical Literary in Iran, Translated by Ebrahim Shurabi, Cairo.

Darghahi, M. (1998). Naghde Shere dar Iran, Amir Kabir Publisher.

Divsalar, F. \& Seyeh Mazhari, M. (2013). Glorifications of Names and attributes of God in Persian Poems, Journal of American Science, 9, 6, 290-294.

Eqbal Ashtiani, A. (2005). Tarikhe Monghol az Hamle e Changhiz, Amir Kanir Publisher.

Hassan ibn Hani, A.N. (1970). Divan, Baghdad, Daro Al- Maktab Al- Saghafa Al- Arabia.

Karbon Hanry, Takhayol in Erfan Ibn Arabi, Translated by Rahmati, Jami publisher, Tehran.

Mahmood Anvar, A. (2001). Sa'adi and Motanabbi, Tehran, Anvare Danesh Publisher.

Moein, M. (2002). Farhange Farsi, Adena publisher, Tehran.

Moayed Shirazi, J. (1997). Simaye Sa'adi, Shiraz University publisher, Shiraz.

Moayed Shirazi, J. (1983). Shenakhti Taze Az Sa'adi, Navid publisher, Shiraz.

Sajjadi, S. J. (1982). Tajalli Erfan dar Adab e Farsi, Nehzate Zanan.

Sa'adi. (1993). Arabic poems of Sa'adi, Edited by Jafar Moayed Shirazi, Shiraz University publisher.

Sa'adi. (2001). Kolliat (Collected Poems), Edited by Frooghi Mihammad Ali, Tehran.

Safa, A. (2005). Historical literary in Iran, Ferdoos publisher, Tehran. 